\title{
The 2005/2006 Avian Influenza Monitoring of Wild Birds and Commercial Poultry in Switzerland
}

\author{
Silvia Dalessi, ${ }^{\mathrm{A}}$ Richard Hoop, ${ }^{\mathrm{A}}$ and Monika Engels ${ }^{\mathrm{B}}$ \\ ${ }^{A}$ Institute of Veterinary Bacteriology, National Reference Center for Poultry and Rabbit Diseases, Vetsuisse Faculty, \\ University of Zurich, Winterthurerstrasse 270, Zurich 8057, Switzerland \\ ${ }^{B}$ Institute of Virology, Vetsuisse Faculty, University of Zurich, Winterthurerstrasse 266a, Zurich 8057, Switzerland
}

Received 1 April 2006; Accepted 26 July 2006

\begin{abstract}
SUMMARY. In October 2005, the second Swiss national avian influenza monitoring in wild waterfowl and commercial poultry with free range management started. Cloacal swabs were examined by real-time reverse transcription-polymerase chain reaction for both $\mathrm{M}$ gene of influenza A virus and $\mathrm{H} 5$ subtype. The monitoring (more than 2000 samples tested) documented the introduction of H5N1 in Swiss wild waterfowl in mid-February 2006. Until the end of March, 29 water bird carcasses were found H5 positive. In the same period, domestic poultry flocks with a permit of free-range management were kept under surveillance, with negative results.
\end{abstract}

RESUMEN. Seguimiento de influenza aviar durante los años 2005/2006 en aves silvestres y aves comerciales en Suiza.

En Suiza, en el mes de octubre del 2005, se inició el segundo seguimiento de influenza aviar en aves silvestres acuáticas y aves comerciales con manejo en pastoreo. Se examinaron hisopos cloacales por la prueba de transcriptasa reversa, reacción en cadena por la polimerasa en tiempo real (por sus siglas en Inglés rtRT-PCR), para la detección tanto del gen M; como del subtipo H5 del virus de influenza aviar. El seguimiento con más de 2000 muestras examinadas documentó la introducción del virus H5N1 en aves acuáticas salvajes en Suiza a mediados del mes de febrero del 2006. Al finalizar el mes de marzo, 29 canales de aves silvestres acuáticas fueron encontradas positivas a H5. En este mismo período, fueron puestos bajo vigilancia epidemiológica lotes de aves comerciales con manejo en pastoreo, encontrando resultados negativos para la presencia de virus de influenza aviar.

Key words: avian influenza, wild bird, monitoring, H5N1, Switzerland

Abbreviations: $\mathrm{AI}=$ avian influenza; $\mathrm{AIV}=$ avian influenza virus; $\mathrm{FAM}=5$-carboxyfluorescein; $\mathrm{H}=$ hemagglutinin; $\mathrm{HPAI}=$ high pathogenicity avian influenza; $\mathrm{LPAI}=$ low pathogenicity avian influenza; $\mathrm{M}=$ matrix; $\mathrm{N}=$ neuraminidase; $\mathrm{PCR}=$ polymerase chain reaction; $\mathrm{RT}=$ reverse transcriptase; $\mathrm{RT}$-PCR $=$ reverse transcription-polymerase chain reaction; TAMRA $=5$-carboxytetramethylrhodamine

Wild waterfowl are the natural reservoir of avian infection (AI) viruses (AIVs) $(1,8)$. All 16 hemagglutinin $(\mathrm{H})$ and nine neuraminidase $(\mathrm{N})$ subtypes have been isolated from wild aquatic birds and shorebirds; the majority of them carry these viruses with no apparent clinical signs $(9,16)$. Previous European AI surveys on migratory birds from flyways across Europe showed differing virus prevalence depending on location, year, and bird species $(6,7)$.

The highly pathogenic $\mathrm{H} 5 \mathrm{~N} 1$ subtype of genotype " $\mathrm{Z}$ " emerged in Southeast Asia at the end of 2002, causing significant damage to the poultry industry and claiming a considerable number of human lives. Until 2005, the outbreaks were restricted to a number of Asian countries, including Indonesia, Vietnam, Thailand, and China $(13,17)$. Although initial outbreaks were mainly reported in commercial poultry, this subtype also led to unusually high mortality in wild waterfowl (14). During mid-2005, an unprecedented outbreak of highly pathogenic $\mathrm{H} 5 \mathrm{~N} 1 \mathrm{AI}$ among migratory birds was reported in Lake Qinghai, China. More than 1000 water birds were affected (11). A few weeks later, the first $\mathrm{H} 5 \mathrm{~N} 1$ outbreaks were reported from Russia and Kazakhstan in both poultry and wild birds. It was the beginning of a rapid geographical spread of this lethal virus strain. To date, outbreaks in poultry and avian wildlife have occurred in more than 40 countries across Asia, the Middle East, Africa, and Europe.

In accordance with the European Union legislative provisions for the survey of AI in Europe, Switzerland performed its first national wild bird monitoring program between autumn 2004 and early spring 2005. Samples from 989 migratory birds were analyzed. Low pathogenicity AI strains were found in two cases (3). A second extended monitoring program was started in October 2005. Until end of March 2006, more than 2000 cloacal swabs were examined by real-time reverse transcription-polymerase chain reaction (RT-PCR) for both $\mathrm{M}$ gene and $\mathrm{H} 5$ subtype of AIV.

\section{MATERIALS AND METHODS}

Birds. Three groups of wild birds were monitored:

1. Birds captured during tagging activities in an important passage place for migratory songbirds and on a significant rest area for migratory waterfowl. These actions lasted from October 1 to December 31, 2005.

2. Birds shot during the waterfowl hunting season from November 2005 to February 2006 in seven Swiss cantons.

3. "Die offs," i.e., unusually high mortality events in wild birds. From ?2 October 2005 to mid-February 2006, samples from incidents with more than five dead birds in one place were collected. After the first reports of $\mathrm{H} 5 \mathrm{~N} 1$-positive swans in western Europe (mid-February 2006), the survey was extended and special teams collected all water birds found dead daily.

In addition, domestic poultry (mainly ducks, geese, and ratites) with a special permit to be kept outdoors during a ban of free-range commercial poultry (initiated February 20, 2006) were tested twice over a period of $6 \mathrm{wk}$.

Sample collection. Ornithologists, hunters, or veterinarians collected cloacal swabs of both wild and domestic birds; the swabs were placed in Viral Culturette ${ }^{\mathrm{TM}}$ tubes (Becton Dickinson Microbiology Systems, Sparks, MD) and sent to the laboratory within $24 \mathrm{hr}$ of collection. The majority of samples were instantly processed; the rest were stored at $-80 \mathrm{C}$ until processing.

Reference strains. The following AIV strains were used in all PCR runs:

- Plasmid: A/duck/Ukraine/63 (H3N8), M gene in $\mathrm{pCR}^{\circledR} 2.1-\mathrm{TOPO}^{\circledR}$ vector

- A/turkey/Mass/65 (H6N2)

- $\mathrm{A} /$ turkey/Wis/66 (H9N2)

- $\mathrm{A} / \mathrm{duck} / \mathrm{Cz} / 56$ (H4N6)

- A/turkey/Turkey (Türkiye)/05 (H5N1) 
Table 1. Order, species, number, and provenience of the wild birds tested.

\begin{tabular}{|c|c|c|c|c|c|c|c|c|c|}
\hline \multirow[b]{2}{*}{ Order } & \multirow[b]{2}{*}{ Species } & \multicolumn{2}{|c|}{ Ringing } & \multicolumn{2}{|c|}{ Hunting } & \multicolumn{2}{|c|}{ Die-offs } & \multirow{2}{*}{$\begin{array}{l}\text { Total } \\
\text { birds }\end{array}$} & \multirow{2}{*}{$\begin{array}{c}\text { Total } \\
\text { positive }\end{array}$} \\
\hline & & Total & Positive & Total & Positive & Total & Positive & & \\
\hline \multirow[t]{6}{*}{ Anseriformes } & Pochard (Aythya farina) & 104 & 0 & 82 & 0 & 60 & 6 & 246 & 6 \\
\hline & Mute swan (Cygnus olor) & & & & & 131 & 1 & 131 & 1 \\
\hline & Mallard (Anas platyrhynchos) & 15 & 0 & 77 & 0 & 33 & 1 & 125 & 1 \\
\hline & Teal (Anas crecca) & & & 19 & 0 & 1 & 0 & 20 & 0 \\
\hline & Goosander (Mergus merganser) & & & & & 6 & 1 & 6 & 1 \\
\hline & Others & 4 & 0 & 16 & 0 & 16 & 0 & 36 & 0 \\
\hline \multirow[t]{2}{*}{ Gruiformes } & Coot (Fulica atra) & 48 & 0 & 6 & 0 & 148 & 4 & 202 & 4 \\
\hline & Others & 8 & 0 & 0 & 0 & 0 & 0 & 8 & 0 \\
\hline Pelicaniformes & Cormorant (Phalacrocorax carbo sinensis) & 64 & 0 & 30 & 0 & 5 & 0 & 99 & 0 \\
\hline \multirow[t]{2}{*}{ Charadriiformes } & Black-headed gull (Larus ridibundus) & 67 & 0 & & & 2 & 0 & 69 & 0 \\
\hline & Yellow-legged gull (Larus cachinnans) & 22 & 0 & & & & & 22 & 0 \\
\hline \multirow[t]{7}{*}{ Passeriformes } & Chaffinch (Fringilla coelebs) & 211 & 0 & & & & & 211 & 0 \\
\hline & Brambling (Fringilla montifringilla) & 107 & 0 & & & 7 & 0 & 114 & 0 \\
\hline & Great tit (Parus major) & 47 & 0 & & & 1 & 0 & 48 & 0 \\
\hline & Song thrush (Turdus philomelos) & 35 & 0 & & & 1 & 0 & 36 & 0 \\
\hline & Blackbird (Turdus merula) & 35 & 0 & & & 7 & 0 & 42 & 0 \\
\hline & Siskin (Carduelis spinus) & 18 & 0 & & & & & 18 & 0 \\
\hline & Other Passeriformes & 64 & 0 & & & 26 & 0 & 90 & 0 \\
\hline \multirow[t]{2}{*}{ Accipitriformes } & Buzzard spp. (Buteo sp.) & & & & & 24 & 0 & 24 & 0 \\
\hline & Others & & & & & 20 & & 20 & \\
\hline Other orders & & 7 & 0 & 17 & 0 & 52 & 0 & 76 & 0 \\
\hline Total & & 967 & 0 & 306 & 0 & 810 & 29 & 2085 & 29 \\
\hline
\end{tabular}

Reference strains and plasmid were provided by the Institute Friedrich-Loeffler, Insel Riems, Germany, and by the Veterinary Laboratories Agency, Weybridge, U.K.

RNA extraction. Swabs were placed in $1.5 \mathrm{ml}$ of phosphatebuffered saline; $750 \mu \mathrm{l}$ was further processed for RNA isolation with the RNeasy Mini kit (QIAGEN AG, Basel, Switzerland) according to the manufacturer's instructions.

Real-time RT-PCR. Method 1: October 2005-January 2006. The samples were amplified by one-step real time RT-PCR with melt curve analysis on an iCycler ${ }^{\mathrm{TM}}$ thermal cycler (Bio-Rad, Hercules, CA). The forward and reverse primers were selected from conserved regions of the gene for the matrix protein $(\mathrm{M})$ of influenza $A$ virus, as described in van Elden et al. (15): INFA-1 F, 5'-GGA CTG CAG CGT AGA CGC TT3'; and NFA-2 R, 5'-CAT CCT GTT GTA TAT GAG GCC CAT-3'. A $50-\mu \mathrm{l}$ PCR was performed using $10 \mu \mathrm{l}$ of extraction product (diluted 1:5 in RNAse free water, heated for $5 \mathrm{~min}$ at $95 \mathrm{C}$, and then cooled on ice), $25 \mu \mathrm{l}$ of iScript ${ }^{\mathrm{TM}}$ one-step RT-PCR Mix with SYBR ${ }^{\circledR}$ Green (Bio$\mathrm{Rad}), 4 \mu \mathrm{l}$ each primer $(400 \mathrm{nM}), 1 \mu \mathrm{l}$ of iScript ${ }^{\mathrm{TM}}$ reverse transcriptase (RT) for one-step RT-PCR (Bio-Rad), and $6 \mu \mathrm{l}$ of RNAse-free water. Thermal cycling conditions were as follows: $10 \mathrm{~min}$ at $50 \mathrm{C}$ for reverse transcription, $5 \mathrm{~min}$ at $95 \mathrm{C}$ for RT deactivation, 45 cycles of $15 \mathrm{sec}$ at $95 \mathrm{C}, 10 \mathrm{sec}$ at $62.5 \mathrm{C}, 70 \mathrm{sec}$ at $65 \mathrm{C}$ for amplification, and $1 \mathrm{~min}$ at $95 \mathrm{C}, 1 \mathrm{~min}$ at $55 \mathrm{C}$, and 80 cycles from $55 \mathrm{C}$ to $95 \mathrm{C}(0.5 \mathrm{C}$ increasel cycle) for melt curve analysis.

Method 2: February-March 2006. The samples were examined with a TaqMan one-step real-time RT-PCR for both the $\mathrm{M}$ and the $\mathrm{H} 5$ gene on an Applied Biosystems 7500 Fast Real-Time PCR System (Applied Biosystems, Foster City, CA). Primers and fluorogenic probe for the M gene were selected according to Spackman et al. (12), with modifications by the Institute of Virology and Immunoprophylaxis, Mittelhäusern, Switzerland: FluPanA F, 5'-AGA TGA GYC TTC TAA CCG A-3'; FluPanA R, 5'-GCA AGA ACA TCT TCA AGT YTC-3'; and FluPanA Pro, 5-carboxyfluorescein (FAM)-TCA GGC CCC CTC AAA
GCC GA-5-carboxytetramethylrhodamine (TAMRA). Primers and fluorogenic probe for the $\mathrm{H} 5$ subtype were selected according to Spackman et al. (12), with modifications from the Veterinary Laboratories Agency, Weybridge, U.K.: H5LH1, 5'-ACA TAT GAC TAC CCA CAR TAT TCA G-3'; H5RH1, 5'-AGA CCA GCT AYC ATG ATT GC-3'; and H5PRO: FAM-TCW ACA GTG GCG AGT TCC CTA GCA-TAMRA. A 30- $\mu$ l PCR was performed using $3 \mu \mathrm{l}$ of extraction product, $15 \mu \mathrm{l}$ of $2 \times$ Master Mix without UNG (Applied Biosystems), $0.75 \mu \mathrm{l}$ of $40 \times$ MultiScribe and RNase Inhibitor Mix (Applied Biosystems), $2.7 \mu \mathrm{l}$ of each $\mathrm{M}$ or $\mathrm{H} 5$ primer (final concentration $900 \mathrm{nM}$ ), $0.75 \mu \mathrm{l}$ of $\mathrm{M}$ or $\mathrm{H} 5$ probe (final concentration $250 \mathrm{nM}$ ), and $5.1 \mu \mathrm{l}$ of RNAse-free water. Thermal cycling conditions were as follows: $30 \mathrm{~min}$ at $48 \mathrm{C}$ for reverse transcription, $10 \mathrm{~min}$ at $95 \mathrm{C}$ for RT deactivation and polymerase activation, and 55 cycles of $15 \mathrm{sec}$ at $95 \mathrm{C}, 1 \mathrm{~min}$ at $60 \mathrm{C}$ for amplification.

Confirmational tests. $\mathrm{H} 5$ positive specimens (cloacal swab and extraction product) were sent to the Veterinary Laboratories Agency for confirmation and $\mathrm{N}$ subtyping.

\section{RESULTS}

Table 1 summarizes order, species, number, and results of the wild bird monitoring. Fig. 1 shows geographical distribution of $\mathrm{H} 5$-positive cases. The first $\mathrm{H} 5$-positive bird was a goosander (Mergus merganser) found dead on the Geneva Lake on February 26. Until March 25, another 28 dead birds (22 from the family Anatidae, four from the family Rallidae, and two from the family Podicipedidae) also tested positive. All of them originated from the Lake of Constance and along the first $20 \mathrm{~km}$ of the Hochrhein River (outfall of the Lake of Constance). In the H5 PCR amplification plot, the cycle threshold values of positive specimens varied from 26 


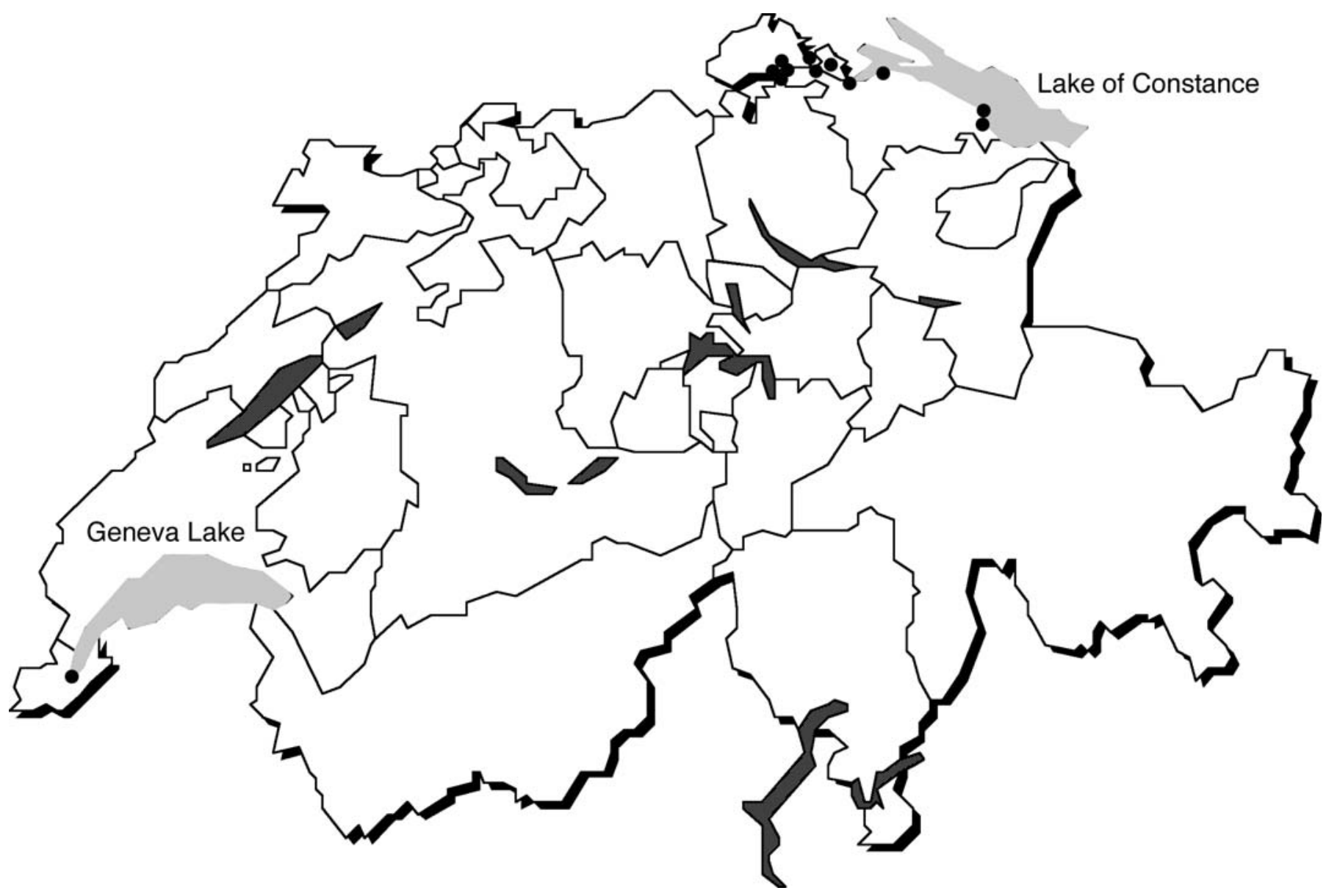

Fig. 1. Map of Switzerland. Locations with H5-positive cases are marked with black points.

to 40 . All of the 110 domestic poultry flocks with special free-range permission were free from AIV.

\section{DISCUSSION}

Switzerland has officially been free of highly pathogenic avian influenza (HPAI) in domestic poultry since 1930 (2). In past years, monitoring was performed by egg culture of every reported case of wild bird die-offs or unusual mortality in commercial poultry, always with AIV negative results (2001-03: 198 cases). Moreover, serologic monitoring of free-range commercial poultry and fancy breeds (18) never gave indication of low pathogenic avian influenza (LPAI) infection (2001-05: 427 flocks). The low AI prevalence was confirmed by the results of the 2004/2005 national wild bird AI monitoring: only two of 989 wild birds tested were found positive (3). In the current study, no AI-positive cases were recorded in more than 1300 wild birds tested until mid-February 2006. Although a considerable part $(39 \%)$ of the samples originated from songbirds (not representing the natural AIV reservoir), the low prevalence contrasts with data from neighboring countries with high prevalence in water birds. Possible explanations for this difference are the considerable nonmigrant part of the Swiss waterfowl and the lack of important migratory routes across Switzerland, with the Alps being a natural barrier. The populations of migratory birds that have their resting places in Northern Germany or the Netherlands only invade Switzerland only during strong winter periods. This invasion happened twice in the last century, i.e. 1939/1940 and 1962/1963 (M. Kestenholz, pers. Comm.).
A further explanation for the low AI prevalence concerns both the choice of cloacal swabs as testing material and the RNA extraction method used. The latter (RNeasy Mini kit) is not the most appropriate method for RNA recovery from wild bird cloacal samples, which can contain endogenous PCR inhibitors. Furthermore, different researchers assert that tracheal swabs are better suited than cloacal swabs for H5N1 detection (13). For both these reasons, tracheal sampling and/or the TRIzol extraction (Invitrogen AG, Basel, Switzerland) are to be favored to achieve a lower virus detection limit in future monitoring actions.

In this study, AI positive birds were detected shortly after the first $\mathrm{H} 5 \mathrm{~N} 1$ reports in western Europe. They were all $\mathrm{H} 5$ positive and found close to the Swiss border, in proximity to the places where France and Germany signalized H5 cases as well (Department Ain, France; Baden Württemberg, Germany). The positive bird originating from Geneva Lake was a female goosander and remained a single isolated case. It is known that the females of this species spend the whole year on Geneva Lake (M. Kestenholz, pers. Comm.). This is a strong indication that $\mathrm{H} 5 \mathrm{~N} 1$ was introduced by migratory birds, presumably from France. The cycle threshold value of the PCR was 27, providing evidence of a high viral load in the feces. The reason why no other cases occurred in that region since February 26 remains obscure.

The remaining $28 \mathrm{H} 5 \mathrm{~N} 1$-positive birds were found on the Lake of Constance, which is a large lake on the Rhine between Germany, Switzerland, and Austria, and along $20 \mathrm{~km}$ of the outcoming watercourse (Hochrhein). The first positive bird there was a whooper swan (Cygnus cygnus, Anseriformes). Contrary to mute swans (Cygnus 
olor), whooper swans are rarely seen in Switzerland. This could have been the index case in that region.

The Lake of Constance is the most important water bird wintering place of the European inland, with wide shallow water areas, where especially tufted ducks (Aythya fuligula), pochards (Aythya ferina), and coots (Fulica atra) can find their main food source, i.e., zebra mussels (Dreissena polymorpha) on the bottom of the lake. In winter, by far the biggest water bird population of Switzerland (180,000 birds, 39\%) (4) is found on these waters.

On both lakes mentioned above, control zones of 3-km range were established, and special teams patrolled the lakeshores and the riverbanks daily to collect dead water birds. Also, dead birds of prey and scavenging birds such as gulls and crows, known as having an action radius of up to $2 \mathrm{~km}$ and not bound to water, were collected to estimate the risk of $\mathrm{H} 5 \mathrm{~N} 1$ spread to commercial poultry. Virus spread to other areas and bird populations was not observed. The actual situation is rather favorable, because $90 \%$ of the winter water bird population $(500,000$ specimens, mid-January (4) will have returned to their Northern breeding areas by mid-April. Virus spreading in the thinned out spring population is less probable as gathering of birds decreases.

Despite the promising situation, there are still concerns that $\mathrm{H} 5 \mathrm{~N} 1$ could spread to domestic poultry. Even if $\mathrm{H} 5 \mathrm{~N} 1$ cases remain in a controlled area or disappear with the migratory hosts, in spring other populations of migratory birds - mainly songbirds such as swallows (Hirundo rustica) — come back from their African wintering sites (among which are Nigerian regions), representing a danger of $\mathrm{H} 5 \mathrm{~N} 1$ reintroduction. These migratory long flyers were monitored starting in April 2006. Possible persistence of $\mathrm{H} 5 \mathrm{~N} 1$ in resident waterfowl (e.g., mallards [Anas platyrhynchos] with 10,000-20,000 breeding pairs) (5) must be verified as well.

Switzerland is preventively keeping all commercial poultry and fancy breeds indoors. A first free-range ban period (substantially politically based and enforced without exceptions) was ordered starting October 15, 2005, for 7 wk. The second, open-ended ban started on February 20. Special permits to enable free-range management, primarily due to the mating behavior of some bird species, e.g. geese, ducks, and ratites, were generously allowed. These flocks are tested twice within a 6-wk period. Further voluntary controls, mainly in fancy breeds, and serologic testing of commercial free-range poultry are planned.

The role of mammals in the spread of H5N1 still needs to be established. Experimental data on infection and epidemiology of $\mathrm{H} 5 \mathrm{~N} 1$ in mammals is sparse (10). In this study, the majority of the H5N1-positive birds showed signs of significant scavenging (e.g., absence of internal organs), presumably by foxes or other wild predators. Even an unexpected high number of domestic cats brought home dead waterfowl; two of these birds were $\mathrm{H} 5 \mathrm{~N} 1$ infected. Although several studies confirmed that domestic cats can be infected with $\mathrm{H} 5 \mathrm{~N} 1$ by eating infected bird meat (10), clinical examination and RT-PCR testing of the felines in this study showed a negative result (data not shown).

In conclusion, the fundamental role of systematic and global monitoring for future sustainable prevention and control of highly pathogenic AI must be emphasized.

\section{REFERENCES}

1. Alexander, D. J. A review of avian influenza in different bird species. Vet. Microbiol. 74:3-13. 2000.

2. Anonymous. Mitteilungen, Bundesamt für Veterinärwesen. 13:220. 2006.
3. Baumer, A. Aviäre Influenza: molekularbiologische Untersuchung von Wildvögeln und seroscreening von Wirtschaftsgeflügel in der Schweiz. Ph.D. Dissertation. University of Zurich, Zurich, Switzerland. 2005.

4. Burkhardt, M., and V. Keller. Vögel am Wasser. Bericht 2003. Schweizerische Vogelwarte. Sempach. 2003.

5. Burkhardt, M., and H. Schmid. Vögel in der Schweiz. Schweizerische Vogelwarte. Sempach. 2001.

6. Fouchier, R. A. M., B. Olsen, T. M. Bestebroer, S. Herfst, L. van der Kemp, G. F. Rimmelzwaan, and A. D. M. E. Osterhaus. Influenza A virus surveillance in wild birds in northern Europe in 1999 and 2000. Avian Dis. 47:857-860. 2003.

7. Globig, A., E. Starick, and O. Werner. Untersuchung von Wildvögeln auf aviäre Influenza- und Paramyxoviren. In: Referatesammlung 67. Fachgespräch der Deutschen Veterinärmedizinischen Gesellschaft, Fachgruppe "Geflügelkrankheiten" 73-82. 2005

8. Kaleta, E. F., G. Hergarten, and A. Yilmaz. Avian influenza A viruses in birds - an ecological, ornithological and virological review. Dtsch. Tierärztl. Wschr. 112:441-480. 2005.

9. Krauss, S., D. Walker, S. P. Pryor, L. Niles, L. Chenhong, V. S. Hinshaw, and R. G. Webster. Influenza A viruses of migrating wild aquatic birds in North America. Vector Borne Zoonotic Dis. 4:177-189. 2004.

10. Kuiken, T., G. Rimmelzwaan, D. van Riel, G. van Amerongen, M. Baars, R. Fouchier, and A. Osterhaus. Avian H5N1 influenza in cats. Science 306:241. 2004.

11. Liu, J., H. Xiao, F. Lei, Q. Zhu, K. Qin, X. Zhang, X. Zhang, D. Zhao, G. Whang, Y. Feng, J. Ma, W. Liu, J. Wang, and G. F. Gao. Highly pathogenic $\mathrm{H} 5 \mathrm{~N} 1$ influenza virus infection in migratory birds. Science 309:1206. 2005.

12. Spackman, E., D. A. Senne, T. J. Myers, L. L. Bulaga, L. P. Garber, M. L. Perdue, K. Lohman, L. T. Daum, and D. L. Suarez. Development of a real-time reverse transcriptase PCR assay for type A influenza virus and the avian $\mathrm{H} 5$ and $\mathrm{H} 7$ hemagglutinin subtypes. J. Clin. Microbiol. 40: 3256-3260. 2002.

13. Sturm-Ramirez, K. M., D. J. Hulse-Post, E. A. Govorkova, J. Humberd, P. Seiler, P. Puthavathana, C. Buranathai, T. D. Nguyen, A. Chaisingh, H. T. Long, T. S. P. Naipospos, H. Chen, T. M. Ellis, Y. Guan, J. S. M. Peiris, and R. G. Webster. Are ducks contributing to the endemicity of highly pathogenic avian influenza virus in Asia? J. Virol. 79:1126911279. 2005.

14. Sturm-Ramirez, K. M., T. Ellis, B. Bousfield, L. Bissett, K. Dyrting, J. E. Rehg, L. Poon, Y. Guan, M. Peiris, and R. G. Webster. Reemerging H5N1 influenza viruses in Hong Kong in 2002 are highly pathogenic to ducks. J. Virol. 78:4892-4901. 2004.

15. Van Elden L. J. R., M. Nijhuis, P. Schipper, R. Schuurman, and A. M. van Loon. Simultaneous detection of influenza viruses A and B using real-time quantitative PCR. J. Clin. Microbiol. 39:196-200. 2001.

16. Webster, R. G., W. J. Bean, O. T. Gorman, T. M. Chambers, and Y. Kawaoka. Evolution and ecology of influenza A viruses. Microbiol. Rev. 56:152-179. 1992.

17. Webster, R. G., Y. Guan, L. Poon, S. Krauss, R. Webby, E. Govorkova, and M. Peiris. The spread of the H5N1 bird flu epidemic in Asia in 2004. Arch. Virol. 19:117-129. 2005.

18. Wunderwald, C., and R. K. Hoop. Serological monitoring of 40 Swiss fancy breed poultry flocks. Avian Pathol. 31:157-162. 2002.

\section{ACKNOWLEDGMENTS}

We thank the Friedrich-Loeffler Institute and the Veterinary Laboratories Agency for providing the reference strains. We are also grateful to Mr. Matthias Kestenholz of the Vogelwarte Sempach for competent ornithological advice and to all ornithologists, hunters, and veterinarians who collected the samples. 